\title{
A santidade no serviço público: um caminho para suplantar a ética e a moral
}

\author{
Holiness in public service: \\ a pathway to supplant ethics and morals
}

Sérgio Carlos Zavaris

\section{Resumo}

O presente artigo tem por objetivo discorrer sobre realidades dos servidores públicos frente ao atual comportamento da sociedade brasileira e as perspectivas de um caminho que suplante os limites éticos e morais para uma mudança de atitude. Para tanto é feito um exame do cenário de disputas que engessam a capacidade de análise das pessoas e é abordada a realidade do servidor público, em geral, examinando sua principal mazela: a corrupção. Por fim, é proposto um paradigma de santidade como confluência da doutrina cristã. Em linhas gerais, o artigo também aborda questões relativas às relações de poder que ocorrem nos diversos espaços da sociedade brasileira, discutindo e tecendo considerações acerca do processo de diálogos com os desafios e tentações que habitam o coração humano. As contribuições desse artigo apontam direcionamentos alicerçados na fé cristã e na doutrina social da Igreja Católica, com apelo à construção de uma sociedade mais justa e solidária, visando culminar na civilização do amor.

Palavras-chave: Religião e estado. Servidor público e corrupção. Ética e moral.

\section{Abstract}

The present article aims to discuss the realities of public servants due to 
the current behavior of the Brazilian society and the perspectives of a path which could overcome ethical and moral boundaries to reach an attitude shift. For this purpose, an examination of the scenario of disputes that hinder people's analysis capacity is made. And an approach to the reality of the public servant, in general, is conducted, with a look at the main stain on his reputation: corruption. Finally, a paradigm of holiness is proposed as a confluence of the Christian doctrine. In general, the article also addresses issues related to relations of power, which occur in different spaces of the Brazilian society, discussing and making considerations about the process of dialogues with the challenges and temptations that inhabit the human heart. The contributions of this article point to directions based on the Christian faith and the social doctrine of the Catholic Church, calling for the construction of a more just and solidary society, aiming to culminate in the civilization of love.

Keywords: Religion and state. Public servant and corruption. Ethics and morals.

\section{Introdução}

O pensamento interdisciplinar, transdisciplinar e integral há muito tempo persegue a rotina do autor, que buscou muito cedo conhecer ciências tão díspares quanto incompatíveis: a odontologia e a engenharia. Uma trajetória que, a partir da graduação, era conduzida em paralelo (os referidos cursos) com a docência do ensino de inglês. Talvez por isso, a vocação latente da interdisciplinaridade se estendeu nos trabalhos de investigações, os quais somaram à inteligência artificial aplicada ao ensino da língua inglesa e aprofundou na tese de doutorado sobre a educação com a epistemologia da integração do conhecimento.

As experiências de estudo despertaram o desejo constante de trabalhar a transversalidade e interdisciplinaridade dos conhecimentos descobertos no caminho acadêmico. E ganharam inspiração na vivência da fé cristã, com contornos mais intensos no debate das políticas públicas, do bem comum, do serviço público e da política, em si. Aliás, a integralidade da pessoa humana é apropriadamente abordada por Dom Joel, quando fala da missão da Igreja na construção de uma cultura de paz: 
A experiência cristã, ao contrário das separações ou oposições reducionistas, afirma a integralidade da pessoa humana e, por consequência, a integralidade e a articulação das diversas dimensões. (...) Os reducionismos, sejam eles quais forem, sempre contribuirão em linha contrária, pois serão apenas a vista a partir de um único aspecto, com a pretensão, porém, da totalidade. ${ }^{1}$

Tais dimensões podem, em última análise, emergir mais visceralmente por quem experimentou, ele próprio, o desafio de compreender ciências e realidades antagônicas e posteriormente se dedicou a realizar estudos que compreendem o vasto universo da integralidade do conhecimento e do homem, já que nem eles mesmos se dissociam entre si para uma existência autônoma. Pois, quem seria o homem sem o conhecimento? E o que seria do conhecimento sem o homem? Portanto, a integralidade da pessoa humana não pode prescindir da interdisciplinaridade e da integralidade como fonte de inspiração para a confluência do que se deve (ou se pode) concluir no processo investigativo, visando lançar luzes para um mundo melhor. "A interdisciplinaridade então, depende de uma mudança de atitude frente ao problema do conhecimento, da substituição de uma concepção fragmentária pela concepção unitária do ser humano". ${ }^{2}$

Assim, o homem como um ser integral não pode se desvincular da sua vocação mais profunda que está na raiz da sua origem, que é Deus - pois ele veio de Deus. E faz todo sentido declarar o quanto o conjunto das atividades humanas precisa estar alinhado com a integralidade completa - do planeta, do próprio homem e da vida. "Deus destinou a terra, com tudo que ela contém, para o uso de todos os homens e de todos os povos, de tal modo que os bens criados devem bastar a todos, com equidade, segundo a regra da justiça, inseparável da caridade". ${ }^{3}$

O trabalho desenvolvido a seguir é fruto da observação, investigação e discernimento sobre os desafios da realidade temporal que afligem a consciência de todos: As economias de todos os países se veem diante da dialética de um estado mínimo em contraposição com um estado social (ou máximo). A crise imposta pela pandemia do coronavírus SARS-CoV-2/COVID-19 está derretendo a economia global e levando vários países a repensar seus modelos econômicos, de políticas públicas e de estado.

\footnotetext{
${ }^{1}$ AMADO, J. P., A missão da Igreja na construção de uma cultura de paz, p. 147.

${ }^{2}$ FAZENDA, I. C. A., Integração e Interdisciplinaridade no Ensino Brasileiro, p. 97.

${ }^{3}$ GS 69.
} 
Por isso, não obstante as mazelas que perpassam o serviço público e, em especial o servidor público, é fundamental advogar que as soluções para um país como o Brasil não estarão em um estado mínimo, tampouco em um estado máximo. O sensato é lutar por um estado justo. Que seja capaz de atender com responsabilidade e zelo aquelas necessidades e serviços que o povo merece e tem direito. E mais do que isso: a nação brasileira não pode, nem deve, prescindir.

Dessa forma, a importância de abordar este tema se faz na expectativa de contribuir com direções para as soluções e está alicerçado na fé, na esperança e na caridade. Não por acaso, virtudes teologais, as quais nutrem todo aquele que quer seguir Jesus - caminho, verdade e vida - única esperança para nós e para o mundo todo.

\section{Discernimento da realidade atual: Cabo de guerra}

Antes de se examinar o servidor público e a sua necessária verdadeira vocação para ser servo de um povo e responder com responsabilidade na prestação de um serviço público, importante se faz apresentar como prelúdio dessa discussão uma análise de conjuntura, evocando-se o discernimento, como uma capacidade de perceber e julgar as coisas, à luz do Espírito Santo de Deus, para identificar realidades e aspectos culturais que parecem nutrir o inconsciente coletivo de uma nação inteira.

Entrementes, é preciso também reconhecer que uma crise muito mais profunda e ampliada está em curso nos dias de hoje. Alguém pode pensar que se trata da crise econômica mundial em razão da pandemia, mas é algo ainda mais grave, pois refere-se à crise do próprio sistema capitalista e a lógica liberal que esgotou sua dinâmica de bolhas e o crescente aumento da pobreza e da miséria no mundo. O autor do livro "21 lições para o século 21", Yuval Noah Harari, descreve um cenário preocupante:

Em 1920, um trabalhador agrícola dispensado devido à mecanização da agricultura era capaz de achar um novo emprego numa fábrica de tratores. Em 1980, um operário de fábrica desempregado poderia trabalhar como caixa num supermercado. Essas mudanças de ocupação eram possíveis porque a mudança do campo para a fábrica e da fábrica para o supermercado só exigiam um retreinamento limitado. Em 2050, porém, um caixa ou um operário da indústria têxtil que perder seu emprego para 
um robô dificilmente estará apto a começar a trabalhar como oncologista, como operador de drone ${ }^{4}$ ou como parte de uma equipe humanos-IA num banco. Não terão as habilidades necessárias. (...) apesar do aparecimento de muitos novos empregos humanos, poderíamos assim mesmo testemunhar o surgimento de uma nova classe de "inúteis".

O que nos dá uma melhor perspectiva dos problemas que realmente se avizinham no horizonte e que termina por desnudar a triste realidade dos traços de individualismo e imediatismo que a raça humana sempre padeceu, mas que se agrava em um planeta que ultrapassou o contingente de mais de sete bilhões de habitantes. O pecado do homem que no passado alcançava o espectro doméstico, agora reverbera sobre todo o planeta - trágica realidade de quem não colocou o Criador no centro da vida para perceber o que realmente importa:

Num mundo marcado pelo individualismo, onde as soluções orientam-se, cada vez mais, pelo incentivo à competitividade e por uma teologia da prosperidade, permeada por informações e conhecimentos - nem sempre relevantes - muito superior à capacidade de abstração humana, as pessoas perdem o sentido de sua verdadeira vocação, que é o amor, e abraçam $\mathrm{o}$ individualismo, o hedonismo, o egoísmo, às vezes, sem perceber e se tornam materialistas e consumistas compulsivos. Neste particular, buscar o serviço público ou mesmo, e inclusive, a política como solução dos problemas individuais, se revela contrário ao clamor de Deus presente no coração humano e que quer aflorar como a noção mais autêntica da nossa vocação aqui na terra: o amor ao próximo. ${ }^{6}$

$\mathrm{Na}$ Epístola aos Gálatas, São Paulo contrapõe, de maneira brilhante, o princípio divino do "livre arbítrio" às seduções que rondam a mente humana e as consequências de uma postura leniente para com o exigente exercício do amor:

Vós, irmãos, fostes chamados à liberdade. Não abuseis, porém, da liberdade como pretexto para prazeres carnais. Pelo contrário, fazei-vos

\footnotetext{
${ }^{4}$ Nota do Autor: Exige conhecimentos de Geoprocessamento, informática e habilidades motoras específicas.

${ }^{5}$ HARARI, Y. N., 21 lições para o século 21, p. 98.

${ }^{6}$ ZAVARIS, S. C., Apostila do MFP/RCCBRASIL, p. 2.
} 
servos uns dos outros pela caridade, porque toda a lei se encerra num só preceito: Amarás o teu próximo como a ti mesmo (Lv 19,18). Mas, se vos mordeis e vos devorais, vede que não acabeis por vos destruirdes uns aos outros (Gl 5,13-15).

De toda sorte, sabemos que o homem é um ser gregário e como tal a interação entre seus pares sempre existiu como parte da essência humana. Também não é novidade que a sociedade atual está cada vez mais conectada e interagindo em tempo real, fazendo com que o volume de informação literalmente "despejado" sobre o indivíduo ultrapasse, em muito, a capacidade mediana de absorção e compreensão e torna a grande maioria de nós, autômatos de um modo de vida que não escolhemos de fato.

Isto tem levado a grande maioria das pessoas a não saberem pensar. $\mathrm{E}$ a enxergarem uma realidade dualista para compreensão dos problemas. $\mathrm{O}$ que faz com que diante de tais análises rasas, os indivíduos sejam levados a assumir uma das opções apresentadas ou compreendidas, como sendo a opção certa ou verdadeira, segundo uma lógica de simplificação imposta pela limitada capacidade cognitiva que a pessoa dispõe.

A questão é que, ao assumir uma das opções como a opção correta ou verdadeira, o indivíduo também assume um comportamento passional a respeito da sua escolha, fazendo com que não lhe seja possível distinguir ele mesmo da sua opinião. Com isso, ele confunde a sua reputação com a opção em si, a qual, eventualmente, nem é fruto de uma análise profunda e embasada. Ao contrário, trata-se de uma análise feita em uma tábua rasa que pouco consegue conter para permitir uma compreensão efetiva.

Resultado: parece que entra em cena a dinâmica do "torcedor do time de futebol" que confunde sua própria integridade emocional e psíquica, com a realidade dualista que se lhe é apresentada e a escolha eventualmente feita com base em modelos simplificadores, os quais lhe são propostos e, não raras vezes, buscam acomodar as visões parciais e distorcidas da realidade complexa do mundo para atender a interesses que não são os seus.

Bem, dito isto, não é um espanto que o momento atual brasileiro se mostre um verdadeiro "cabo de guerra" em torno das realidades políticas. Quando muito, as políticas públicas conseguem ser listadas como uma escolha de "torcida", pois em sua essência, ou é de direita, ou é de esquerda. E conforme a escolha inicial construída em bases frágeis, o cidadão parte do 
pressuposto que tudo que vem com o mesmo rótulo deve, obrigatoriamente, caber na mesma caixa dos pré-conceitos antes estabelecidos.

Exemplo clássico dessa realidade é o serviço público e a dialética do socialismo versus liberalismo. As duas ideologias "parecem" pressupor um estado democrático de direito. Porém, assumem os modelos simplistas, onde o socialismo advoga em favor de um estado inchado e o liberalismo em favor de um estado mínimo. Isto faz com que o consenso popular (para não dizer, das redes sociais) ataque veementemente o serviço público, de um modo geral, e o servidor público, em particular. Este último passa a ser o opróbrio da escolha profissional e objeto do praguejamento geral. Capaz inclusive de ser identificado como culpado do infortúnio da nação brasileira e o grande vilão de todas as crises do país.

$\mathrm{Na}$ esteira desse raciocínio, o estado de bem-estar social torna-se pueril e o capitalismo assume o protagonismo do atendimento de toda uma população, o que sabidamente esbarra na lógica do lucro e nos vícios do pecado original, que estão presentes em qualquer modelo de estado.

Destarte, na sociedade líquida atual, todos são muito rápidos em apontar o dedo aos supostos culpados e transformam-se imediatamente em cidadãos exemplares, embora, na verdade, cultivem o hábito de jogar lixo no chão, entrar indevidamente em lugar na fila, estacionar em local proibido, sonegar os impostos, subtrair a verdade ou mentir quando o interesse próprio está em jogo, etc. Ou como diria Dom Joel a respeito da teoria de Bauman:

Já se convencionou chamar de mudança de época. Nesta, os valores maiores, as referências mais profundas e os critérios que levam a discernimentos e atitudes passam, no conhecidíssimo dizer de Zygmunt Bauman, por um processo de liquefação, tornando impossível serem retidos e fornecerem a necessária segurança existencial. ${ }^{7}$

Efetivamente, percebe-se que somos vítimas do sistema de comunicação atual, que convencionamos chamar de "mídia". No passado, a concentração de divulgação nas mãos de poucos permitia a manipulação da informação. Hoje, a disseminação via redes sociais tem nos revelado uma face ainda mais dramática: "Fake News". De qualquer forma, mantem-se a realidade da expressão "vida de gado", na qual se diz que o povo é guiado, como gado, para o lugar que o vaqueiro desejar.

${ }^{7}$ AMADO, J. P., A missão da Igreja na construção de uma cultura de paz, p. 146. 
Fato é que, apesar da real necessidade de os serviços públicos serem confiados a alguém que os entregue responsavelmente ao povo de nosso país, parece ser mais fácil criar o caos e sucumbir a máquina pública-eventualmente, visando emergir novos nichos de negócios para a iniciativa privada - do que propor soluções que resgatem o serviço público, como essência do bem comum, e valorizem o servidor público como espelho daqueles que deveriam ter um chamado especial para servir o povo.

De toda sorte, concentrando-se na questão do servidor público como colaborador dos interesses da nação brasileira para cuidar do bem comum, existem outros aspectos a serem observados, cuja abordagem veremos a seguir.

\section{Benefício e compromisso: Servidor público}

Se, por outro lado, olhamos para a questão de frente, é razoável identificar que nenhuma nação é capaz de oferecer tão pouco serviço público ao cidadão que permita aproximar a carga tributária de zero, objeto recursivo do pleito de quem defende o estado mínimo e que tende a querer aviltar a importância das políticas públicas, do serviço público e do servidor público.

Exemplo clássico é a magistratura, onde juízes são constantemente acusados de altos salários. Faz-se, desse modo, uma associação de alto salário com alto imposto - baixos salários com baixos impostos. Essa pode até ser a lógica capitalista, onde baixo salário significa aumento de lucro. Mas em uma realidade de dimensões continentais como o Brasil não é bem assim. Se o país não conseguir diminuir o desperdício, a corrupção, a sonegação e o mau emprego dos recursos públicos (financeiros e humanos) os governos continuarão a demandar uma arrecadação gigantesca de imposto.

Interessante notar que a teoria de preços (Lei da oferta e demanda) é frequentemente esquecida na análise de impostos. Assim como a demanda de um produto varia conforme seu preço, também o resultado da arrecadação de impostos varia conforme a carga tributária - quando a carga tributária é baixa e todos pagam (sem sonegação), o resultado da arrecadação aumenta. E isso já foi comprovado!

A questão da comparação de salários do setor público com o setor privado torna-se discrepante quando se compara com a realidade cruel do povo e não com parâmetros profissionais. No caso de juízes e advogados do setor privado, que é o exemplo citado, os defensores desta tese se esquecem que, não raro, um profissional do direito que seja bem sucedido ganhará muito mais do que 
qualquer juiz em final de carreira. Certa vez, em um discurso político, um governador de estado fez referência a essa diferença salarial argumentando que para quem quer ganhar dinheiro, política é um péssimo negócio, pois se alguém tem competência para exercer um cargo político importante, seguramente este alguém tem a necessária competência para empreender no mundo dos negócios e ganhar muito mais dinheiro. Lógica rasa, mas eficaz: corrupto é uma pessoa que emprega sua inteligência e capacidade para trabalhar no lugar errado e enriquecer com o dinheiro dos outros, isto é, do modo errado.

Em que pesem as mazelas reais de toda a questão, será razoável uma nação inteira passar a maldizer aqueles de quem esperam serem servidos dos serviços públicos e pelos quais acreditam pagar com pesados impostos? Ora, se a solução não está na maldição sobre uma categoria de trabalhadores até que ela desapareça - fato insólito e de resultado questionável - que outra abordagem pode lançar luzes e esperança para o futuro?

É importante lembrar que segundo a Constituição Federal, o provimento das vagas no serviço público é realizado por três tipos de servidores públicos: servidor eleito, servidor concursado e servidor comissionado (cargo de confiança), conforme a legislação brasileira:

\begin{abstract}
A investidura em cargo ou emprego público depende de aprovação prévia em concurso público de provas ou de provas e títulos, de acordo com a natureza e a complexidade do cargo ou emprego, na forma prevista em lei, ressalvadas as nomeações para cargo em comissão declarado em lei de livre nomeação e exoneração. ${ }^{8}$
\end{abstract}

Contudo, é preciso reconhecer que a práxis comum no exercício dos cargos públicos tem dois atributos: benefício do cargo e certeza de impunidade. Quanto ao benefício do cargo, normalmente, o servidor acredita no direito do poder nele investido pelo mérito pessoal de seus próprios esforços. Já quanto a certeza de impunidade, o servidor adquire a sensação de ser imune às cobranças, independente do seu desempenho.

É certo que diante da possibilidade de uma remuneração que não varia de acordo com o empenho do trabalhador e cuja estabilidade the garante impunidade mesmo diante de um desempenho medíocre, muitos servidores se veem tentados a uma atuação limitada com o emprego de um esforço mínimo necessário para o cumprimento do ofício.

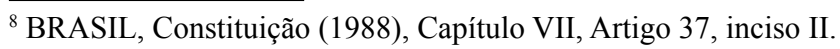


De fato, essa pode ser a grande diferença que caracteriza as realidades público e privada no Brasil. Para o setor público não importa se o servidor trabalha muito ou pouco. Seu salário é sempre o mesmo - diante disso, ele se economiza e limita os resultados produzidos. Já para o setor privado, o céu é o limite e por isso muitos trabalhadores estarão dispostos a subtrair sua própria vida na busca desenfreada por melhores salários e oportunidades, muitas vezes, renunciando à sua família, amigos, laser, saúde e até adoecendo prematura e permanentemente.

Entretanto, para além das realidades de baixo desempenho e produtividade medíocre, como formas de corrupção não tão bem qualificáveis no arcabouço jurídico atual, preocupa ainda mais a corrupção qualificada na lei e que normalmente é associada aos servidores públicos eleitos: o político.

Verdadeiro pecado social, a corrupção não só subtrai os recursos públicos do erário, como também contamina a sociedade com uma reafirmação de uma cultura de pecado e, por que não dizer, de morte.

\section{Pedra de tropeço: Corrupção e Pecado}

Meu filho, nada faças sem conselho, e não te arrependerás depois de teres agido. Não te embrenhes num caminho de perdição e não tropeçarás nas pedras. Não te metas num caminho escabroso, para não pores diante de ti uma pedra de tropeço (Ecl 32,24-25).

Há uma distinção basilar entre corrupção e pecado. Corrupção é crime. Já o pecado, nem sempre. Não que isto signifique atenuante para o pecado, o qual, por sua vez, impõe o afastamento de Deus, o que é extremamente grave. E termina por significar a perda da Salvação eterna, com a consequente privação do paraíso. Evidentemente, o pecado pressupõe ser passível de reconciliação com Deus, através do sacramento de mesmo nome. Assim, todo ato de corrupção é sempre um pecado, embora nem todo pecado seja um ato de corrupção, em termos legais. Mas o peso escatológico sobre a corrupção parece ultrapassar o do pecado.

Poderíamos dizer que pecado se perdoa, a corrupção não pode ser perdoada. Simplesmente porque na base de toda atitude corrupta há um cansaço de transcendência: diante do Deus que não se cansa de perdoar, o corrupto se erige como suficiente na expressão de sua saúde e cansa-se de pedir perdão. ${ }^{9}$

\footnotetext{
${ }^{9}$ BERGOGLIO, J., Corrupção e pecado, p. 27.
} 
Outrossim, há uma distinção entre o pecado que pode ser perdoado através do sacramento da reconciliação e o pecado social, cujo sujeito ou autor nem sempre é claramente identificado. O que remete ao dilema da reconciliação sem confessor. Por ser um pecado coletivo ou solidário, reside uma dificuldade em se conceder o perdão. A quem perdoar? Quem pediria (ou deveria pedir) perdão? $\mathrm{Na}$ eventualidade de confissão, dificilmente todos iriam se confessar - como conceder um perdão parcial? O Papa Francisco, quando ainda era cardeal em Buenos Aires, identificou, de maneira muito sensata, a relação atribuída à corrupção e ao pecado. "Com frequência noto que se relaciona corrupção com pecado. Na verdade, não é bem assim. Situação de pecado e estado de corrupção são duas realidades diferentes, embora intimamente entrelaçadas". ${ }^{10}$

Assim sendo, abordar corrupção e pecado pode levar a uma discussão teológica sobre o pecado mais densa do que o espaço disponível em um artigo, remetendo o tema para outras investigações e arrazoados futuros. Diante disso, abordaremos especialmente a corrupção como desvio consciente de atos praticados pelo servidor público (eleito ou concursado), tornando o ato numa ação pessoal e intransferível. A existência do cidadão como corruptor é evidente, entretanto a corrupção não prosperaria diante de um serviço público constituído por servidores incorruptíveis.

Neste sentido, nossa abordagem tem como premissa que todo ato de corrupção será sempre um pecado social, porque lesa a sociedade direta ou indiretamente, conforme se pode depreender do seu significado no dicionário: "Ato ou efeito de subornar alguém para vantagens pessoais ou de terceiros. Uso de meios ilícitos, por parte de pessoas do serviço público, para obtenção de informações sigilosas, a fim de conseguir benefícios para si ou para terceiros". ${ }^{11}$

Como referido, o Código Penal Brasileiro estabelece a corrupção em apenas duas modalidades: corrupção passiva e corrupção ativa. Sendo que a corrupção passiva é prevista no Artigo 317 como sendo um crime que se caracteriza por: "Solicitar ou receber, para si ou para outrem, direta ou indiretamente, ainda que fora da função ou antes de assumi-la, mas em razão dela, vantagem indevida, ou aceitar promessa de tal vantagem: Pena reclusão, de 2 (dois) a 12 (doze) anos, e multa". ${ }^{12}$

\footnotetext{
${ }^{10}$ BERGOGLIO, J., Corrupção e pecado, p. 10.

${ }^{11}$ MICHAELIS, Corrupção.

${ }^{12}$ BRASIL, Código Penal, Senado Federal, Título XI, Capítulo I, Artigo 317.
} 
Já a corrupção ativa, por sua vez, é prevista no Artigo 333 e é caracterizado por: "Oferecer ou prometer vantagem indevida a funcionário público, para determiná-lo a praticar, omitir ou retardar ato de ofício: Pena - reclusão, de 2 (dois) a 12 (doze) anos, e multa". ${ }^{13}$

Neste contexto, é relevante considerar a existência de indivíduos com genuínas dificuldades cognitivas para distinguir o certo do errado, o legal do ilegal, tornando-se presas fáceis de um sistema viciado, culturalmente pervertido e legislativamente confuso. Pois, muitas vezes, há instituições com pessoas mergulhadas na corrupção que a transformam em verdadeira organização criminosa; há uma cultura dominante que exalta a "Lei de Gerson" e valoriza a figura do malandro; e há leis que nem sempre são fáceis de serem compreendidas e postas em prática. Por fim, há incautos que se perdem, embora sem álibi, nem desculpas, no relativismo cultural e no pluralismo ético que atua fortemente na sociedade de hoje.

Constata-se hoje um certo relativismo cultural, que apresenta sinais evidentes da sua presença, quando teoriza e defende um pluralismo ético que sanciona a decadência e a dissolução da razão e dos princípios da lei moral natural. Em conformidade com essa tendência, não é raro, infelizmente, encontrar, em declarações públicas, afirmações que defendem que esse pluralismo ético é condição para a democracia. Assim, verifica-se que, por um lado, os cidadãos reivindicam para as próprias escolhas morais a mais completa autonomia e, por outro, os legisladores julgam respeitar essa liberdade de escolha, quando formulam leis que prescindem dos princípios da ética natural, deixando-se levar exclusivamente pela condescendência com certas orientações culturais ou morais transitórias, como se todas as concepções possíveis da vida tivessem o mesmo valor. Ao mesmo tempo, invocando erroneamente o valor da tolerância, pede-se a uma boa parte dos cidadãos - entre eles, aos católicos - que renunciem a contribuir para vida social e política dos próprios países segundo o conceito da pessoa e do bem comum que consideram humanamente verdadeiro e justo, a realizar através dos meios lícitos que o ordenamento jurídico democrático põe, de forma igual, à disposição de todos os membros da comunidade política. ${ }^{14}$

De toda sorte, seja por ingenuidade, seja por adesão ao relativismo cultural, é patente a incompatibilidade para o exercício de um cargo público.

${ }^{13}$ BRASIL, Código Penal, Senado Federal, Título XI, Capítulo II, Artigo 333.

${ }^{14}$ Nota doutrinal, 6 . 
Não obstante, fica colocado em relevo o papel da Igreja e a importância da formação cristã, abrindo portas para oportunidades de acolhimento e acompanhamento desses filhos, que não são órfãos de Deus.

Sabemos que o pecado tem como origem o consentimento da tentação e que a corrupção também nasce da tentação assumida. Mas para Bergoglio o pecado e a tentação são contagiosos, enquanto a corrupção é proselitista.

Há três características de toda tentação ao pecado: a tentação cresce, contagia e se justifica. Essas mesmas características aparecem, mas de modo diverso, no estado de corrupção. A corrupção se consolida, convoca e assenta doutrina. $\mathrm{O}$ crescer da tentação já é processo de consolidação; o contagiar passa a ter um papel ativo, e por isso é proselitismo; finalmente, a simples justificativa se elabora muito mais e assenta doutrina. ${ }^{15}$

O Papa Francisco chama a atenção para o coração do homem como fonte de nossas ações, destacando que é no coração o lugar em que o indivíduo nutre as aspirações que o tornam bom ou mal, sendo possível para cada pessoa buscar o conhecimento de si mesmo e orientar sua vida conscientemente na direção da luz de Deus. "Porque onde está o teu tesouro, lá também está teu coração" (Mt 6, 21).

Conhecer o coração do homem, seu estado, implica necessariamente conhecer o tesouro a que esse coração se refere, o tesouro que o liberta e plenifica ou que o destrói e escraviza; neste último caso, o tesouro que o corrompe. De tal modo que a corrupção (pessoal ou social) passa ao coração, que se torna seu autor e conservador, e do coração passa ao tesouro no qual esse coração está aderido. ${ }^{16}$

A partir daí o dono desse coração já não julga com sensatez e se vê compelido a usar expedientes como da mentira, da dissimulação, da traição, do egoísmo e do ódio, que termina por levá-lo, cada vez mais, à prática da corrupção, como um ato natural. "Nem sempre alguém se transforma de repente em corrupto. Há um caminho pelo qual a pessoa vai deslizando. E esse caminho não se confunde facilmente com o caminho de cometer pecados". ${ }^{17}$

\footnotetext{
${ }^{15}$ BERGOGLIO, J., Corrupção e pecado, p. 99.

${ }^{16}$ BERGOGLIO, J., Corrupção e pecado, p. 21.

${ }^{17}$ BERGOGLIO, J., Corrupção e pecado, p. 55.
} 
Ao observar casos de corrupção, muitas vezes, parece que se está diante de indivíduos com distúrbio psicológico de dupla personalidade, quando o universo de justificativas utilizadas pela vítima não guardam coerência entre a vida que professam e a prática do que realmente vivem. Por isso, quando o Papa São João Paulo II escreveu sobre a vocação e missão dos leigos na igreja e no mundo, na exortação apostólica pós-sinodal Christifideles Laici, nos disse:

Ao descobrir e viver a própria vocação e missão, os fiéis leigos devem ser formados para aquela unidade, de que está assinalada a sua própria situação de membros da Igreja e de cidadãos da sociedade humana. Não pode haver na sua existência duas vidas paralelas: por um lado, a vida chamada "espiritual", com os seus valores e exigências; e, por outro, a chamada vida "secular", ou seja, a vida da família, do trabalho, das relações sociais, do empenhamento político e da cultura. ${ }^{18}$ (Grifo nosso)

Por outro lado, quando o indivíduo acredita que o poder investido nele é fruto de seus próprios méritos, ele dá o primeiro passo na direção da soberba, prepotência, arrogância, autossuficiência e abre espaço para a corrupção. Diria o Cardeal Jorge Bergoglio: "como é difícil que o vigor profético alquebre um coração corrupto! Está tão escudado na satisfação de sua autossuficiência, que não permite nenhum questionamento". ${ }^{19}$

Talvez seja preciso dizer que surge a identificação de um estágio mais grave de corrupto, ao qual o Papa Francisco chamou de imanência.

No corrupto existe uma suficiência básica, que começa sendo inconsciente e depois é assumida como a coisa mais natural. A suficiência humana nunca é abstrata. É uma atitude do coração concernente a um tesouro que o seduz, que o tranquiliza e o engana: "E direi à minha alma: ó minha alma, tens muitos bens em depósito para muitíssimos anos; descansa, come, bebe e regala-te" (Lc 12,19). E, de maneira curiosa, dá-se um contrassenso: o suficiente sempre é, no fundo, um escravo desse tesouro e, quanto mais escravo, mais insuficiente na consistência dessa suficiência. ${ }^{20}$

\footnotetext{
${ }^{18}$ CfL 59.

${ }^{19}$ BERGOGLIO, J., Corrupção e pecado, p. 13.

${ }^{20}$ BERGOGLIO, J., Corrupção e pecado, p. 28.
} 


\section{Paradigma para exercício do cargo público: A santidade}

Não é possível construir o perfil, nem alcançar os níveis mais nobres da sociedade com que um servidor público deveria enfrentar o desafio de fazer bem feito o seu ofício sem que esse descubra, ao mesmo tempo, os sinais pelos quais pode confiar que esteja desempenhando uma missão dada por Deus. Sinais que se traduzem em razões que são escatológicas, porque fazem-no entender como construir o reino vindouro e razões teológicas, porque suas atividades estão pautadas nos bens promovidos pela revelação de Cristo. A rigor, somente esta perspectiva poderia ser capaz de ultrapassar a ética profissional e atingir o coração do indivíduo, para um grau mais elevado de honestidade, probidade, compromisso e justiça. E este nível elevado refere-se à santidade. A santidade que quase sempre remete a um patamar inatingível para as pessoas, encontra sua referência em Jesus, que valorizava o amor ao próximo como vocação humana e divina, condenava veementemente a hipocrisia e apontava para a santidade como forma de se chegar mais próximo de Deus e alcançar a Salvação da alma na vida eterna.

A exemplo da santidade daquele que vos chamou, sede também vós santos em todas as vossas ações, pois está escrito: Sede santos, porque eu sou santo ( $\operatorname{Lv} 11,44)$. Se invocais como Pai aquele que, sem distinção de pessoas, julga cada um segundo as suas obras, vivei com temor durante $\mathrm{o}$ tempo da vossa peregrinação (1Pd 1,15-17).

Aliás, o Compêndio da Doutrina Social da Igreja nos exorta que o caminho da santidade é também um caminho de cruz.

Jesus, o Messias prometido, combateu e desbaratou a tentação de um messianismo político, caracterizado pelo domínio sobre as nações $(\mathrm{Mt}$ 4,8-11; Lc 4,5-8). Ele é o Filho do Homem que veio "para servir e entregar a própria vida" (Mc 10,45; Mt 20,24-28; Lc 22,24-27). Aos discípulos que discutem sobre quem é o maior, Jesus ensina a fazer-se último e a servir a todos (Mc 9,33-35), indicando aos filhos de Zebedeu, Tiago e João, que ambicionavam sentar-se à Sua direita, o caminho da cruz (Mc 10,35-40; Mt 20,20-23). ${ }^{21}$

${ }^{21}$ DSI 379. 
Compreender que o caminho da santidade é também um caminho de cruz foge da natureza do ser humano que constantemente busca ser feliz, porque associa felicidade a parâmetros como prazeres, benefícios, confortos, alegrias, conquistas ou bónus. Felicidade é mais do que isso. De fato, felicidade está muito mais para a paz que vem de dentro da pessoa do que dos atributos ao seu redor.

E aqui é preciso reconhecer que a pedagogia de Deus parecer ser desconcertante - por amor, expulsa o homem do paraíso ao mesmo tempo em que o vocaciona a só encontrar a paz quando está em Deus; por amor, oferece seu filho unigênito em sacrifício de reparação do pecado original ao mesmo tempo em que abre a porta da eternidade para o abraço de misericórdia definitivo de um Pai que é só amor.

Como pode, então, alguém querer aproximar-se de Deus, se não perceber que sua verdadeira vocação é doar-se ao próximo por amor a Deus? Compreender este desafio é o primeiro passo para compreender o chamado de Deus para alguma missão. É nesta dimensão que o serviço público se transforma em oportunidade de amor ao próximo.

Eu vos exorto, pois, irmãos, pelas misericórdias de Deus, a oferecerdes vossos corpos em sacrifício vivo, santo, agradável a Deus: é este o vosso culto espiritual. Não vos conformeis com este mundo, mas transformai-vos pela renovação do vosso espírito, para que possais discernir qual é a vontade de Deus, o que é bom, o que lhe agrada e o que é perfeito (1Jo 4,20-21).

São Paulo afirma que há um sentido muito profundo, um valor inestimável, um ganho intangível, que eleva a alma de quem se sacrifica pelas coisas de Deus. Aqui, São Paulo poderia até estar falando para os servidores públicos atuais. Pois o sentido da exortação de Paulo é apelar para que o homem compreenda a verdadeira dimensão da sua própria redenção a partir da oferta de si mesmo em favor de Deus, como verdadeiras hóstias vivas, por aquilo que é nobre, por tudo que é bom e verdadeiro, por aquilo que é correto e justo, o que se contrapõe com a forma do mundo agir e se relacionar com o poder. Para tanto, São Paulo indica a transformação do indivíduo pela renovação do espírito que o anima e, assim, assumir como critério permanente na tomada de decisões: buscar discernir quatro coisas: a) qual é a vontade de Deus, b) o que é bom, c) o que agrada a Deus e d) o que é perfeito. 
Com isso, a pessoa é convidada a perceber que o empenho por ela empreendido no trabalho e no trato da coisa pública - que tem origem em um mandato de Deus - deve alcançar a qualidade e a excelência, independente do retorno tangível ou do ganho, pois, como dito antes, é por amor a Deus. E o verbo amar não comporta ação pela metade, não permite meio termo.

Com efeito, o julgamento de Jesus trás reflexão que sempre deveria visitar o coração de quem acha que tem poder e que este poder é fruto de alguma meritocracia:

(Pilatos) ... entrou novamente no pretório e perguntou a Jesus: "De onde és tu?" Mas Jesus não lhe respondeu. Pilatos então lhe disse: "Tu não me respondes? Não sabes que tenho poder para te soltar e para te crucificar?" Respondeu Jesus: "Não terias poder algum sobre mim, se de cima não te fora dado" (Grifo nosso). (Jo 19,9-11a).

Ou seja, aquele que tem consciência de que mesmo o maior poder do mundo não vem de seus próprios méritos, mas é dado por Deus, deveria assumir, não só o reconhecimento e a dívida para com Deus, mas também a obrigação de retornar a Deus a prerrogativa de conduzir o próprio poder. Pois se veio de Deus, a Ele deve retornar. No mesmo diapasão, é Ele quem deve conduzir. Isto significa que um servidor que ocupa um cargo qualquer (professor, policial, deputado ou presidente da república), deveria buscar a partir do Espírito de Sabedoria de Deus o discernimento para a condução de suas decisões. Mas, infelizmente, quase nunca é assim...

Se é certo que Deus é onipotente, também é certo que todo poder vem Dele. Portanto, qualquer um que se dedique ao verdadeiro exercício do poder somente o consegue exercê-lo de maneira plena, quando o discernimento vem Deus, do contrário é autoritarismo e vaidade. E para isso é preciso buscar a Deus incessantemente, com amor e com temor profundos. Deus se deixa encontrar para aqueles que buscam a Sua justiça na tomada de decisões. "A autoridade, pois, deve deixar-se guiar pela lei moral: toda a sua dignidade deriva do desenrolarse no âmbito da ordem moral, 'a qual tem a Deus como princípio e fim' '”22.

Neste particular, em 2004, sabiamente a CNBB lançou um projeto de evangelização que trouxe uma linda proposta que saiu dos lábios dos gregos: "Queremos ver Jesus" (Jo 12,21b), com a intenção de alimentar o desejo por um genuíno encontro com Deus.

${ }^{22}$ DSI 396. 
A todos nos toca recomeçar a partir de Cristo, reconhecendo que não se começa a ser cristão por uma decisão ética ou uma grande ideia, mas pelo encontro com um acontecimento, com uma Pessoa, que dá um novo horizonte à vida e, com isso, uma orientação decisiva. ${ }^{23}$

E assim, homem ou mulher que se dedique a repetir o zelo de São Paulo no exercício de seu cargo e/ou função como servidor público, correrá o risco de repetir o exemplo de Saulo, que se tornou Paulo. Aquele que embora nunca tenha estado fisicamente na presença de Jesus, se tornou discípulo pela força do encontro pessoal que teve com o Ressuscitado. E foi assim que Paulo se convenceu de que Jesus era, de fato, o Messias e de que Deus verdadeiramente visitou a humanidade, por um ato de amor que ultrapassa toda a lei humana, na mensagem da cruz.

Vê-se que o exercício dos cargos e das funções, para o servidor público, adquire nova dimensão. A dimensão de vocação e missão. A dimensão do chamado que o próprio Jesus faz a quem se vê diante do poder de servir ao povo que, no fim das contas, é de Deus. Não nosso, nem de outrem!

\section{Conclusão}

Ora, não se trata de abordar o tema da santidade para um pequeno grupo de pessoas piedosas, interessadas em participar da vida da Igreja, mas, antes, se trata de inspirar uma nova proposta de vida para todos os cidadãos desejosos de contribuir com o país, o serviço público e o bem comum, como fonte de doação em favor do próximo e, assim, reafirmar o mandamento que Jesus ordenou:

Se alguém disser: Amo a Deus, mas odeia seu irmão, é mentiroso. Porque aquele que não ama seu irmão, a quem vê, é incapaz de amar a Deus, a quem não vê. Temos de Deus este mandamento: o que amar a Deus, ame também a seu irmão (1 Jo 4,20-21).

Com isso, fazer ecoar a Palavra de Deus em todo lugar, principalmente em nossa própria consciência e, especialmente, através de nosso testemunho de vida. Uma vez que o testemunho de Jesus já o recebemos.

${ }^{23}$ DAp 12. 
O comportamento de Deus no governo do mundo, que demonstra tão grande consideração pela liberdade humana, deveria inspirar a sabedoria dos que governam as comunidades humanas. Estes devem comportar-se como ministros da providência divina. ${ }^{24}$

Por fim, ressalta-se que os valores que nutrem a vocação e missão de ser um servidor público não pode ser outra se não o amor e a fé. Em Audiência Geral deste ano de 2020, o Papa Francisco voltou a frisar sobre a importância do amor, inclusive na política e no serviço público:

Se lerdes a história da humanidade, encontrareis muitos políticos, santos, que percorreram este caminho. É possível na medida em que cada cidadão e, em particular, aqueles que assumem compromissos e encargos sociais e políticos, enraízam as suas ações em princípios éticos e as animam com amor social e político. Os cristãos, especialmente os fiéis leigos, são chamados a dar bom testemunho disto e podem fazê-lo através da virtude da caridade, cultivando a sua intrínseca dimensão social. Por conseguinte, chegou o momento de incrementar o nosso amor social - desejo frisar isto: o nosso amor social - contribuindo todos, a começar pela nossa pequenez. $\mathrm{O}$ bem comum requer a participação de todos. Se cada um contribuir com a sua parte, e se ninguém for excluído, podemos regenerar boas relações a nível comunitário, nacional e internacional e também em harmonia com o meio ambiente (LS 236). Assim, nos nossos gestos, mesmo nos mais humildes, tornar-se-á visível algo da imagem de Deus que temos dentro de nós, porque Deus é Trindade, Deus é Amor. Esta é a definição mais bonita de Deus na Bíblia. É-nos oferecida pelo apóstolo João, que amava tanto Jesus: Deus é amor. Com a sua ajuda, podemos curar o mundo trabalhando juntos para o bem comum, não só para o próprio bem, mas para o bem comum, de todos. ${ }^{25}$

O amor a Deus sobre todas as coisas, o qual se revela na manifestação sublime de amor ao próximo e que, neste particular, se caracteriza pelo amor a quem nem se conhece e muitas vezes só eventualmente, alguém que se dedique a praticá-lo, poderá testemunhar qualquer gratidão. Ou seja, efetivamente significa amar alguém, sem olhar a quem. Amar sem esperar retorno ou reconhecimento. Amar como uma exigência de máxima doação e

\footnotetext{
${ }^{24}$ DSI 383.

${ }^{25}$ FRANCISCO, PP., Audiência Geral no Pátio São Dâmaso.
} 
saber que, ao final, talvez ainda não seja o suficiente. E é aí que se percebe que tal expressão de amor se aproxima do amor de Deus e da coragem para amar de Jesus. E, muito provavelmente, só encontra seu apogeu quando sustentado pela fé. A Primeira Carta de João nos dá ânimo e nos dá coragem para prosseguir decididamente:

Todo o que crê que Jesus é o Cristo, nasceu de Deus; e todo o que ama aquele que o gerou, ama também aquele que dele foi gerado. Nisto conhecemos que amamos os filhos de Deus: se amamos a Deus e guardamos os seus mandamentos. Eis o amor de Deus: que guardemos seus mandamentos. E seus mandamentos não são penosos, porque todo o que nasceu de Deus vence o mundo. E esta é a vitória que vence o mundo: a nossa fé (grifo nosso) (1Jo 5,1-4).

\section{Referências bibliográficas}

AMADO, J. P. A missão da Igreja na construção de uma cultura de paz. In: AMADO, J. P.; FERNANDES, L. A. (Orgs.). Cultura da Paz num mundo em conflito. Rio de Janeiro: Editora PUC-Rio / Letra Capital, 2017. p. 145156.

BERGOGLIO, J. M. Corrupção e pecado. São Paulo: Editora Ave Maria, 2013.

BÍBLIA Sagrada Ave-Maria. São Paulo: Editora Ave-Maria, 2018.

BRASIL. Constituição (1988). Constituição da República Federativa do Brasil de 1988. Brasília, DF: Presidência da República, [2020]. Disponível em: <http://www.planalto.gov.br/ccivil_03/constituicao/constituicao.htm>. Acesso em: 29 ago. 2020.

BRASIL. Código Penal. Brasília, DF: Senado Federal / Coordenação de Edições Técnicas, 2017.

CELAM. Aparecida: Texto conclusivo da V Conferência Geral do Episcopado Latino-americano e do Caribe, 13-31 de maio de 2007. Brasília: Edições CNBB; São Paulo: Paulinas / Paulus, 2007.

CONCÍLIO VATICANO II. Constituição Pastoral Gaudium et spes sobre a Igreja no mundo contemporâneo. São Paulo: Edições Paulinas, 1965.

CONGREGAÇÃO PARA A DOUTRINA DA FÉ. Nota doutrinal: sobre 
algumas questões relativas à participação e comportamento dos católicos na vida política. São Paulo: Paulinas, 2003.

HARARI, Y. N. 21 lições para o século 21. São Paulo: Companhia das Letras, 2018.

MICHAELIS. Dicionário Brasileiro da Língua Portuguesa. São Paulo: Editora Melhoramentos, 2020. Disponível em: <https://michaelis.uol.com. br/>. Acesso em: 29 ago. 2020.

FAZENDA, I. C. A. Integração e Interdisciplinaridade no Ensino Brasileiro: Efetividade ou Ideologia?. São Paulo: Edições Loyola, 2002.

FRANCISCO, PP. Audiência Geral no Pátio São Dâmaso. Disponível em: $<$ http://w2.vatican.va/content/francesco/pt/audiences/2020/documents/papafrancesco_20200909_udienza-generale.html>. Acesso em: 09 set. 2020.

JOÃO PAULO II, PP. Exortação Apostólica Cristifideles Laici sobre a vocação e missão dos leigos na Igreja e no mundo. São Paulo: Edições Paulinas, 1990.

PONTIFÍCIO CONSELHO “JUSTIÇA E PAZ". Compêndio da doutrina social da Igreja. São Paulo: Paulinas, 2005.

ZAVARIS, S. C. Apostila do Ministério de Fé e Política. Renovação Carismática Católica do Brasil. São Paulo: Editora RCCBRASIL, 2012. Disponível em: $<$ https://issuu.com/fe.politica/docs/apostila_mfp-2012_rcc $>$. Acesso em: 09 set. 2020.

Sérgio Carlos Zavaris Doutor em Educação pela Universidad Del Mar, Chile Docente Titular no Instituto Federal do Espírito Santo Vitória / ES - Brasil E-mail: zavaris@ifes.edu.br

Recebido em: 31/08/2020

Aprovado em: 11/11/2020 